\title{
Spatio-Temporal Trend Analysis of Groundwater Levels in Sharjah, UAE
}

\author{
Abdullah G. Yilmaz, Abdallah Shanableh, Rami I. Al-Ruzouq, Naseraldin Kayemah
}

\begin{abstract}
United Arab Emirates (UAE) is a water stressed country due to limited rainfall. Moreover, rapid population growth, increase in agricultural and industrial activities are causing additional stress to the water resources in UAE. Groundwater is the most important fresh water source in UAE, and sustainable and efficient management of groundwater is vital for the country. Trend analysis of groundwater levels is an essential component of groundwater management, since it provides significant information about the direction and characteristics of the groundwater level trend, allowable discharge limit and the cause of groundwater decline. In this study, monthly groundwater level trends from eleven well fields were investigated over the period of 15 years in Sharjah, UAE. Groundwater spatiotemporal data analysis tool (GWSDAT) was used for the spatial and temporal trend analysis for groundwater levels. Mann-Kendall non-parametric test was used for the temporal trend analysis. Statistically significant decreasing trends were identified almost in all well fields in Sharjah. In parallel to decreasing groundwater levels, the groundwater production has fallen substantially (more than $90 \%$ decrease in some well fields over 15 years). It was found that the well fields close to the coastline experienced significant decrease in groundwater levels, which induces sea water intrusion and salinization of groundwater.
\end{abstract}

Index Terms - Groundwater levels, Sharjah, spatio-temporal trend analysis, United Arab Emirates.

\section{INTRODUCTION}

Groundwater is an important fresh water source that can meet the domestic, agricultural and industrial water demand. Statistical assessment of groundwater quality and levels is an important task in sustainable management of groundwater, especially in the arid and semi-arid regions, where there is limited surface fresh water resources. The water demand in these regions are met mainly by groundwater and non-conventional water resources such as desalinated water.

Trend analysis of groundwater levels is an essential component of groundwater management, since it provides significant information about the direction and characteristics of the groundwater level trend, allowable discharge limit and the cause of groundwater decline ([1]; [2]). Several studies (e.g. [3]; [4]) showed that trend analysis is very powerful in planning management strategies for development and utilization of groundwater resources. As an example of groundwater level trend analysis studies, [5] studied

Manuscript received July 12, 2019; revised November 2, 2019.

Abdullah Gokhan Yilmaz and Abdallah Shanableh are with University of Sharjah, Australia (e-mial: ayilmaz@sharjah.ac.ae, shanableh@sharjah.ac.ae).

Rami Issa Al-Ruzouq is with University of Sharjah, United States (e-mail: ralruzouq@sharjah.ac.ae).

Naseraldin Kayemah is with University of Sharjah, Syria (e-mail: U18200520@sharjah.ac.ae). groundwater level trends by using non-parametric tests in Ardabil plain of Iran, and they found significant decreasing trends in groundwater levels in the study area. [6] used Mann-Kendall (MK) and Sen's slope tests to detect groundwater level trends in Bangladesh, decreasing trends in the maximum and minimum depths of groundwater levels (during 1991-2010) were reported. [7] investigated spatio-temporal trends in groundwater in Lake Umria region. [8] used regional Kendall method to analyze groundwater levels and their annual decline rates in Beijing, Tianjin and Hebei in China. This study showed a continuing declining regional trend in groundwater levels. [9] reported no significant trend in groundwater levels (with few exceptions) in Raipur city at $95 \%$ significance level by analyzing monthly groundwater level data using MK test and Sen's slope estimator.

United Arab Emirates (UAE) is a water stressed country due to limited rainfall. Moreover, rapid population growth, increase in agricultural and industrial activities are causing additional stress to the water resources in UAE [10]. There is very limited surface fresh water available in UAE due to rare rainfall events (about $110 \mathrm{~mm} /$ year) [11]. Groundwater is used to meet $70 \%$ of total water demand in UAE, and agriculture sector is the highest groundwater consumer with $83 \%$ of total groundwater use [12]. The over-extraction of groundwater and lack of recharge led to a serious decline in the groundwater level and caused sea water intrusion in UAE [13], [14]. In this study, spatio-temporal trends in monthly groundwater levels were investigated in Sharjah, UAE by analyzing data from eleven well fields. This study is expected to provide significant contribution to sustainable groundwater management in Sharjah, and to assist groundwater policymakers in the region for future planning.

\section{STUdy AREA AND DATA}

The study area, Emirate of Sharjah, is located in UAE with central coordinates of $25.3^{\circ} \mathrm{N}$ and $55.5^{\circ} \mathrm{E}$ approximately. Sharjah occupies around 2,590 $\mathrm{km}^{2}$. Fig. 1 shows location of Sharjah along with location of well fields used in this study. The climate in Sharjah is considered hot, dry and humid. Rainy season in Sharjah is from November to March. The available capacity of the groundwater wells is around 21.50 million gallons per day, and daily average water production from groundwater wells is around 15.46 million gallons. $70 \%$ of the total groundwater consumption is for irrigation purposes in Sharjah [15].

In this study, monthly groundwater level data from eleven well fields (i.e., Al Sadiyah, Aweed, Bedai, Filli, Ghuraifa, Hamdah, Madam, Mahafis, Sajaa, Seih Aqareb and Seih Hermal) are considered. As seen in Fig. 1, the well fields are 
approximately evenly distributed between the west and the south parts of Sharjah. The data period ranges between 2004 and 2018 showing variation for different well fields as shown in Table I.

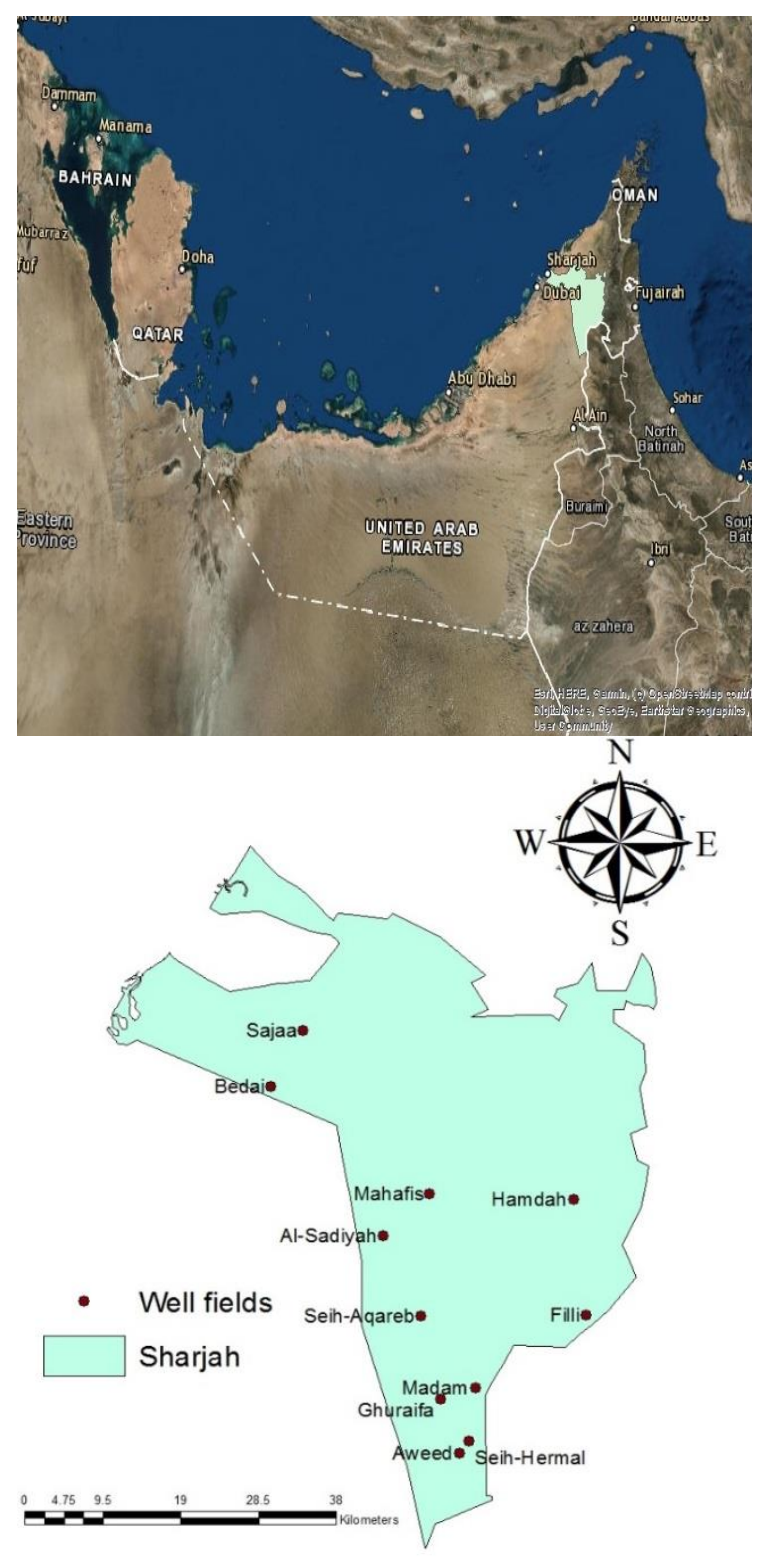

Fig. 1. Location of Sharjah and well fields.

TABLE I: AVAILABLE DATA TIME PERIOD

\begin{tabular}{|l|l|}
\hline Well Field & Data period \\
\hline Al Sadiyah & $2008-2015$ \\
\hline Aweed & $2004-2018$ \\
\hline Bedai & $2006-2009$ \\
\hline Filli & $2010-2016$ \\
\hline Ghuraifa & $2004-2018$ \\
\hline Hamdah & $2004-2016$ \\
\hline Madam & $2004-2018$ \\
\hline Mahafis & $2010-2015$ \\
\hline Sajaa & $2005-2010$ \\
\hline Seih Aqareb & $2004-2018$ \\
\hline Seih Hermal & $2004-2018$ \\
\hline
\end{tabular}

\section{Methodology}

Groundwater spatiotemporal data analysis tool (GWSDAT) was used for the spatial and temporal trend analysis for groundwater levels in this study. Since the groundwater level data is mostly non-normally distributed, MK non-parametric test was used for the temporal trend analysis, whereas penalized splines (P-Splines) smoothing was adopted for spatial trend analysis.

\section{A. Mann-Kendall Test}

The MK is a non-parametric rank-based test and used in several hydro-meteorological trend analysis studies (e.g. [16]-[24]). The z-statistics for this test can be calculated by:

$$
Z=\left\{\begin{array}{c}
\frac{S-1}{\operatorname{Var}(S)} \text { if } S>0 \\
0 \quad \text { if } S=0 \\
\frac{S+1}{\operatorname{Var}(S)} \text { if } S<0
\end{array}\right.
$$

The $S$ value can be computed by:

$$
S=\sum_{k=1}^{n-1} \sum_{j=k+1}^{n} \operatorname{sgn}\left(x_{j}-x_{k}\right)
$$

where $x_{j}-x_{k}$ are the sequential data values, $\mathrm{n}$ is the number of data

$$
\operatorname{sgn}\left(x_{j}-x_{k}\right)= \begin{cases}1 & \text { if } x_{j}-x_{k}>0 \\ 0 & \text { if } x_{j}-x_{k}=0 \\ -1 & \text { if } x_{j}-x_{k}<0\end{cases}
$$

The $\operatorname{Var}(S)$ can be calculated using:

$$
\operatorname{Var}(S)=\frac{n(n-1)(2 n+5)}{18}
$$

Positive test statistics indicate increasing trend, whereas negative test statistic shows decreasing trend in MK test. After calculating $\mathrm{z}$-statistics, normal distribution function is used to calculate the value $\mathrm{p}(P(Z \geq z))$.

$$
\begin{gathered}
P(Z \geq z)=1-P(z) \\
P(Z \geq z)=P(-z)
\end{gathered}
$$

$p$ values equal or smaller than 0.1 indicate a significant trend at $90 \%$ significance level, whereas $p$ values equal or smaller than 0.05 and 0.01 indicate a significant trend at $95 \%$ and $99 \%$ significance levels, respectively.

\section{B. Spatial Analysis}

Spatial analysis of the groundwater level was conducted to understand the variation of groundwater level over space. Non-parametric P-Splines method, which enables estimation of regression functions contrast with more traditional parametric models with greater flexibility in fitting data [25], was used for spatial analysis. More details of P-Splines method are explained in [26], [27].

\section{RESUltS AND DiscUSSION}

\section{A. Temporal Trend Analysis}

Table II shows MK p-values and z statistics for eleven well fields. 
TABLE II: P-VALUE AND Z STATISTICS OF MK TEST

\begin{tabular}{|l|l|l|}
\hline Well field & p value & z statistics \\
\hline Al-Sadiyah & $<-\mathbf{0 . 0 1}$ & $\mathbf{- 6 . 1 4 5}$ \\
\hline Aweed & $<-\mathbf{0 . 0 1}$ & $\mathbf{- 1 4 . 0 2 2}$ \\
\hline Bedai & -0.0437 & -2.017 \\
\hline Filli & $<-\mathbf{0 . 0 1}$ & $\mathbf{- 7 . 4 8 9}$ \\
\hline Ghuraifa & $<-\mathbf{- 0 . 0 1}$ & $\mathbf{- 1 1 . 8 0 2}$ \\
\hline Hamdah & $<-\mathbf{0 . 0 1}$ & $\mathbf{- 1 3 . 1 9 2}$ \\
\hline Madam & $<-\mathbf{0 . 0 1}$ & $\mathbf{- 9 . 1 9 3}$ \\
\hline Mahafis & $<-\mathbf{0 . 0 1}$ & $\mathbf{- 8 . 6 6 5}$ \\
\hline Sajaa & $<-\mathbf{0 . 0 1}$ & $\mathbf{- 9 . 4 0 6}$ \\
\hline Seih-Aqareb & $<-\mathbf{0 . 0 1}$ & $\mathbf{- 1 1 . 0 5 6}$ \\
\hline Seih-Hermal & $<-\mathbf{0 . 0 1}$ & $\mathbf{- 1 2 . 7 5 6}$ \\
\hline
\end{tabular}

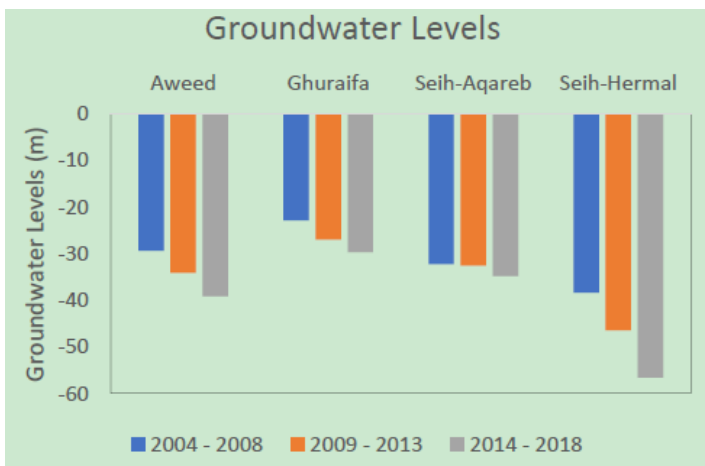

Fig. 2. Groundwater levels for selected well fields.
Fig. 2 shows average annual groundwater levels over three time periods (i.e., 2004-2008, 2009-2013 and 2014-2018) for selected well fields (Aweed, Ghuraifa, Seih-Aqareb and Seih-Hermal).

In Table II, bold numbers indicate statistically significant trends at $99 \%$ significance level. As shown in Table II, decreasing groundwater level trends were detected in all well fields. All detected trends were statistically significant at $99 \%$ significance level except the trends in Bedai well field. Supporting the results in Table II, Fig. 2 shows decreasing trend in groundwater levels over time. As can be seen in Table II, the strongest decreasing trend in groundwater level was detected in Aweed well field followed by Hamdah and Seih-Hermal well fields. The significant decreasing trends can be explained by large agricultural water demand around these three well fields. The groundwater production from these well fields were used to meet irrigation water demand in particular for date farms in the region.

Although the most significant decreasing trends (over time) was found at Aweed well field, the maximum groundwater level decrease occurred in Seih-Hermal well field. Fig. 3 shows the groundwater production values over the period of 2004 - 2018 in well fields including Aweed, Ghuraifa, Seih-Aqareb and Seih-Hermal.

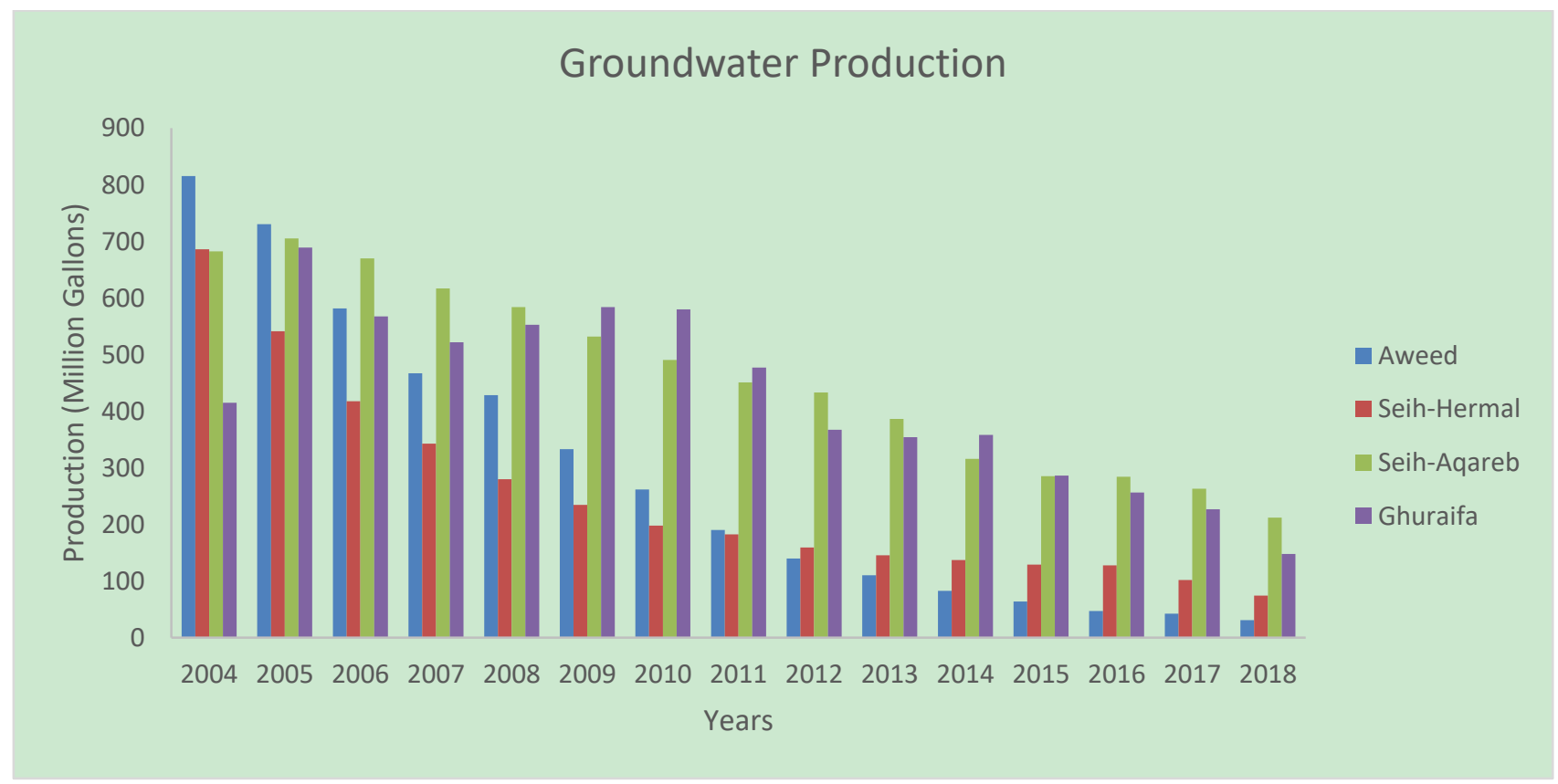

Fig. 3. Groundwater production for selected well fields.

It can be seen from Fig. 3 that the production at 2004 was very high for the selected well fields. The production in Aweed, Seih-Hermal, Seih-Aqareb and Ghuraifa well fields was approximately 815, 685, 682 and 415 million gallons respectively in 2004. The water level in 2004 was approximately 28, 32, 31, $21 \mathrm{~m}$ below the ground level for Aweed, Seih-Hermal, Seih Aqareb and Ghuraifa respectively. However, in 2018 the water levels decreased to around 40, 56, 33, and $32 \mathrm{~m}$ below the ground level in Aweed, Seih-Hermal, Seih Aqareb and Ghuraifa respectively. The decrease in the groundwater level resulted in decreases in groundwater productions (to be approximately 31, 74, 212, 148 million gallons in Aweed, Seih-Hermal, Seih Aqareb and Ghuraifa well fields respectively) in 2018. The significant decrease in water level and production in Aweed and Seih-Hermal explains the high (negative) $\mathrm{z}$-statistics values reached to -14.022 in Aweed and -12.756 in Seih-Hermal.

\section{B. Spatial Analysis}

Spatial analysis was conducted to understand the variation of groundwater levels over the study are. Fig. 4 shows an example of spatial analysis results for the years 2006 (Fig. 4 (a)) and 2009 (Fig. 4(b)). These years were selected, since almost all well fields had groundwater level data for these two years (which made spatial interpolation more reliable). Fig. 4 shows that highest groundwater levels were observed in southeast to east Sharjah, whereas lowest groundwater levels were detected in west to northwest Sharjah. It should be noted that scales in Fig. 4 represents the distance from 
groundwater table to the ground surface. Therefore, lower values in the scale (represented by blue color) indicate higher groundwater level. It can be recognized from Fig. 4 that groundwater levels decreased in all well fields between the years 2006 and 2009. The groundwater level in the well fields close to the coastline (i.e., Bedai and Sajaa) are very low. Also, temporal trend analysis showed significant groundwater level decrease in Sajaa. If the groundwater levels keep decreasing around coastal region, the sea water will intrude to the groundwater aquifer and the groundwater will be saline. This will require advanced treatment of groundwater before using it to satisfy water demands.

Reference [28] studied on assessment of groundwater quality in Sharjah, and they reported that salinity related water quality parameters including Electrical Conductivity (EC), Chloride $\left(\mathrm{Cl}^{-}\right)$and Total Dissolved Solids (TDS) are very high in well fields close to the coastal region. Fig. 5 illustrates well fields very close to sea cost (Bedia, Sajaa and Muhadhab).

Table III shows the average, minimum and maximum values of $\mathrm{EC}, \mathrm{Cl}^{-}$and TDS in groundwater samples from Bedia and Muhadhab well fields along with permissible limits of these parameters according to Abu Dhabi Water Quality Regulations (ADWQR), standard deviation (std) and number of samples (count). It should be noted that groundwater quality data is not available for Sajaa well field.

TABLE III: ILLUSTRATIVE STATISTICS AND PERMISSIBLE LIMITS OF SALINITY RELATED PARAMETERS

\begin{tabular}{|c|c|c|c|c|}
\hline & & $\mathbf{C l}^{-}(\mathbf{m g} / \mathbf{L})$ & $\begin{array}{c}\mathbf{E C} \\
(\boldsymbol{\mu S} / \mathbf{c m})\end{array}$ & $\begin{array}{c}\text { TDS } \\
(\mathbf{m g} / \mathbf{L})\end{array}$ \\
\hline Well fields & Limits & 250 & 1600 & 1000 \\
\hline \multirow{3}{*}{ Bedai } & $\mathbf{A v g}$ & 711 & 3069 & 1960 \\
\cline { 2 - 5 } & $\mathbf{M a x}$ & 1015 & 3982 & 2627 \\
\cline { 2 - 5 } & Min & 460 & 2340 & 1123 \\
\cline { 2 - 5 } & Count & 145 & 145 & 146 \\
\hline
\end{tabular}

\begin{tabular}{|c|c|c|c|c|}
\hline & Std & 116 & 490 & 352 \\
\hline Muhadhab & Avg & 951 & 3663 & 2376 \\
\cline { 2 - 5 } & Max & 1258 & 4269 & 2852 \\
\cline { 2 - 5 } & Min & 647 & 2960 & 1507 \\
\cline { 2 - 5 } & Count & 38 & 38 & 38 \\
\cline { 2 - 5 } & Std & 136 & 317 & 286 \\
\hline
\end{tabular}

As shown in Table III, in Bedai well field, $\mathrm{Cl}^{-}$had values between 460 and $1015 \mathrm{mg} / \mathrm{L}$ with an average of $711 \mathrm{mg} / \mathrm{L}$. The permissible limit of $\mathrm{Cl}^{-}$is $250 \mathrm{mg} / \mathrm{L}$ according to ADWQR. EC values ranged between 2340 and $3982 \mu \mathrm{S} / \mathrm{cm}$ with an average of $3069 \mu \mathrm{S} / \mathrm{cm}$ in Bedai well field. The permissible limit of $\mathrm{Cl}^{-}$is $1600 \mu \mathrm{S} / \mathrm{cm}$ according to ADWQR. TDS had values between 1123 and $2627 \mathrm{mg} / \mathrm{L}$ with an average of $1960 \mathrm{mg} / \mathrm{L}$. The permissible limit of TDS is 1000 $\mathrm{mg} / \mathrm{L}$ according to ADWQR. In Muhadhab well field, $\mathrm{Cl}^{-}$had values between 647 and $1258 \mathrm{mg} / \mathrm{L}$ with an average of 951 $\mathrm{mg} / \mathrm{L}$. EC values in Muhadhab well field ranged between 2960 and $4269 \mu \mathrm{S} / \mathrm{cm}$ with an average of $3663 \mu \mathrm{S} / \mathrm{cm}$. TDS values in Muhadhab well field showed variation between 1507 and $2852 \mathrm{mg} / \mathrm{L}$. The average of TDS values is 2852 $\mathrm{mg} / \mathrm{L}$. All salinity related water quality parameters $\left(\mathrm{Cl}^{-}, \mathrm{EC}\right.$ and TDS) in well fields close to sea had very high values, and these values are very well above the permissible limits. More importantly, there is a significant increasing trend (at $99 \%$ significance level) in $\mathrm{Cl}^{-}, \mathrm{EC}$ and TDS according to trend analysis results shown in Table IV. Positive z statistics in Table IV shows that $\mathrm{Cl}^{-}$, TDS and EC values in well fields close to sea are increasing, and these trends are statistically significant at $99 \%$ confidence level (as p values are smaller than 0.01).

This means that if groundwater levels keep decreasing in these well fields, the groundwater will be saltier, and groundwater will not be a fresh water resource.

TABLE IV: TREND RESULTS IN SALINITY RELATED PARAMETERS

\begin{tabular}{|c|c|c|c|c|c|c|}
\hline & \multicolumn{2}{|c|}{$\mathbf{C l}(\mathbf{m g} / \mathbf{L})$} & \multicolumn{2}{c|}{$\mathbf{E C}(\boldsymbol{\mu S} / \mathbf{c m})$} & \multicolumn{2}{c|}{ TDS $(\mathbf{m g} / \mathbf{L})$} \\
\hline $\begin{array}{c}\text { Well } \\
\text { field }\end{array}$ & z statistics & $p$ value & z statistics & $p$ value & z statistics & $\begin{array}{c}p \\
\text { value }\end{array}$ \\
\hline Bedai & 11.41 & $<0.01$ & 13.58 & $<0.01$ & 11.79 & $<0.01$ \\
\hline Muhadhab & 4.48 & $<0.01$ & 5.78 & $<0.01$ & 5.13 & $<0.01$ \\
\hline
\end{tabular}

(a)

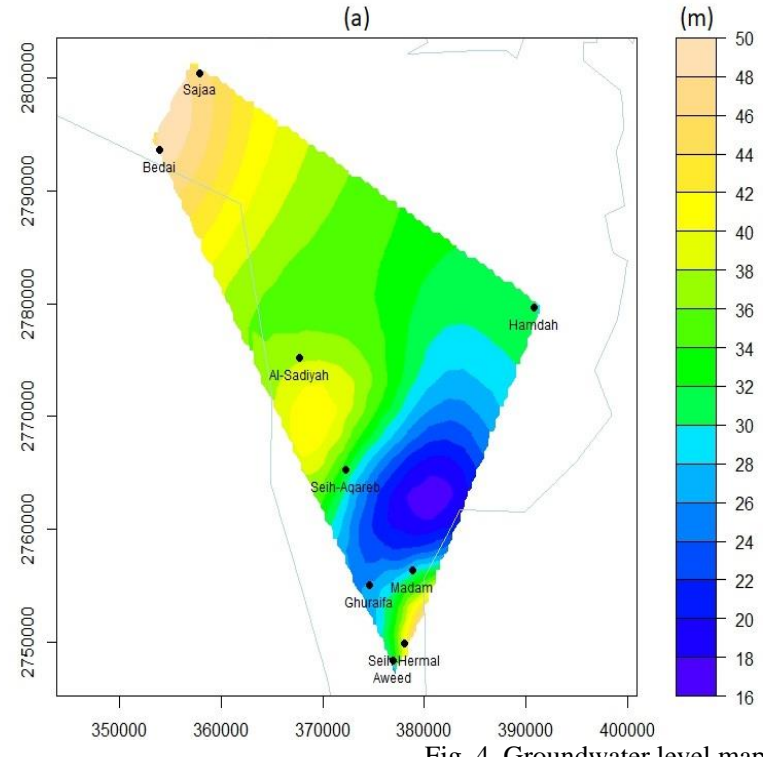

(b)

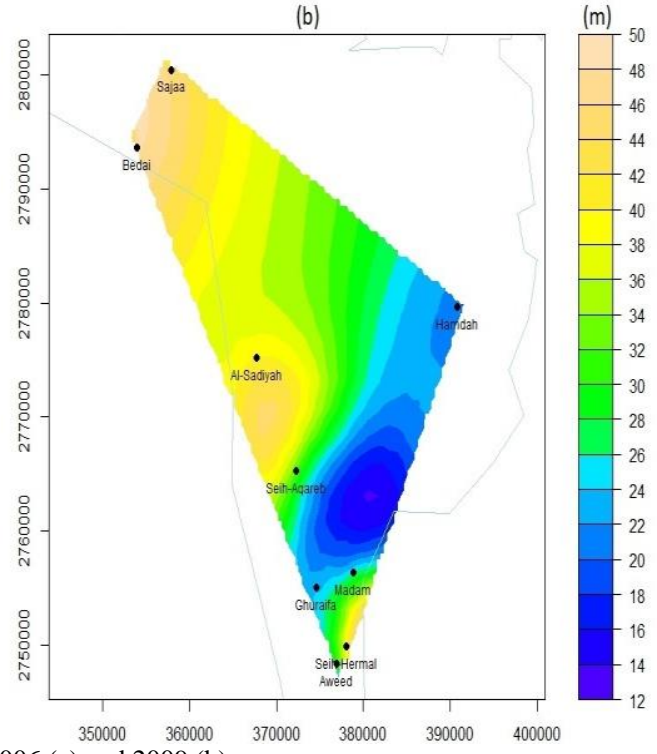

Fig. 4. Groundwater level map in 2006 (a) and 2009 (b). 


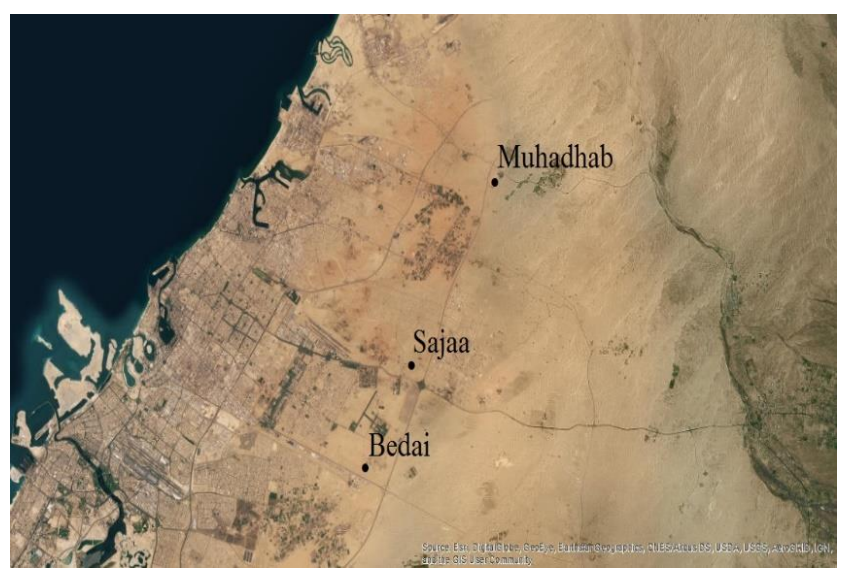

Fig. 5. Location of the well fields close to sea coast.

\section{CONCLUSIONS}

In this study, monthly groundwater level data obtained from eleven well fields were used to conduct spatio-temporal trend analysis of groundwater levels in Sharjah, UAE. The spatial analysis of groundwater levels in Sharjah was conducted by $\mathrm{P}$-spline method, whereas MK non-parametric test was used for the temporal trend analysis. Followings are the major conclusions from this study:

- Decreasing groundwater level trends were detected in all well fields in Sharjah.

- All detected trends were statistically significant at 99\% significance level except the trend in Bedai well field.

- The highest decreasing trend was found in Aweed well field, and the highest decrease in groundwater level was detected in Seih-Hermal well field.

- In parallel to decreasing groundwater levels, the groundwater production has decreased significantly (more than 90\% decrease in some well fields).

- It was found that groundwater levels in well fields close to coastline experienced a significant decrease over time leading seawater intrusion and salinization of groundwater.

- Analysis of salinity related water quality parameters including $\mathrm{Cl}^{-}$, TDS and EC at well fields close to sea showed that these parameters have very high values (very well above the permissible limits).

- Statistically significant increasing trends were detected in $\mathrm{Cl}^{-}$, TDS and EC parameters at well fields close to sea.

- Groundwater level decreases (and increased salinity) in particular at well fields close to sea require immediate action by groundwater managers to protect fresh groundwater.

Findings of this study provide significant input for groundwater management in Sharjah. As a next step, solutions to groundwater level decreases such as artificial recharge of the aquifers, or harvesting the limited rainfall in small dams and natural recharge of the aquifers will be investigated and discussed in further studies.

\section{CONFLICT OF INTEREST}

The authors declare no conflict of interest.

\section{AUTHOR CONTRIBUTIONS}

Abdullah G. Yilmaz supervised the analysis and wrote the paper, Abdallah Shanableh and Rami I. Al-Ruzouq contributed data collection and analysis, and reviewed the paper. Naseraldin Kayemah assisted data analysis.

\section{ACKNOWLEDGMENT}

This research has been supported by the Sharjah Electricity and Water Authority (Grant no. 19020401122-SEWA).

Authors would like to thank SEWA for the support.

\section{REFERENCES}

[1] G. T. Patle, D. K. Singh, A. Sarangi, A. Rai, M. Khanna, and R. N. Sahoo, "Time series analysis of groundwater levels and projection of future trend," J. Geol. Soc. India, vol. 85, pp. 232-242, Feb. 2015.

[2] A. Gibrilla, G. Anornu, and D. Adomako, "Trend analysis and ARIMA modelling of recent groundwater levels in the White Volta River basin of Ghana," Groundwater for Sustainable Development, vol. 6, pp. 150-63. Mar, 2018.

[3] T. J. Mack, M. P. Chornack, and M. R. Taher, "Groundwater-level trends and implications for sustainable water use in the Kabul Basin, Afghanistan," Environment Systems and Decisions, vol. 33, pp. 457-67, Sep, 2013.

[4] M. G. Abdullahi, M. B. Gasim, and H. Juahir, "Determination of Groundwater Level Based on Rainfall Distribution: Using Integrated Modeling Techniques in Terengganu, Malaysia," Journal of Geology \& Geosciences, vol. 4, pp. 1-4, Jan, 2015.

[5] F. D. Vousoughi, Y. Dinpashoh, M. T. Aalami, and D. Jhajharia, "Trend analysis of groundwater using non-parametric methods (case study: Ardabil plain)," Stochastic Environmental Research and Risk Assessment, vol. 27, pp. 547-559, Feb, 2013.

[6] M. Dawood, "Spatio-statistical analysis of temperature fluctuation using Mann-Kendall and Sen's slope approach," Climate Dynamics, vol. 48, pp. 783-797, Feb, 2017.

[7] B. Amirataee and K. Zeinalzadeh, "Trends analysis of quantitative and qualitative changes in groundwater with considering the autocorrelation coefficients in west of Lake Urmia, Iran," Environmental Earth Sciences, vol. 75, pp. 1-10, Mar, 2016.

[8] C. Fang, S. Sun, S. Jia, and Y. Li, "Groundwater level analysis using regional Kendall test for trend with spatial autocorrelation," Groundwater, vol. 57, pp. 320-328, June, 2018.

[9] N. Kumar, B. Tischbein, and M. K. Beg, "Multiple trend analysis of rainfall and temperature for a monsoon-dominated catchment in India," Meteorology and Atmospheric Physics, pp. 1-5 July, 2018.

[10] A. Murad, "An overview of conventional and non-conventional water resources in arid region: Assessment and constrains of the United Arab Emirates (UAE)," Journal of Water Resource and Protection, vol. 2, pp. 181-190, Mar, 2010.

[11] M. Sherif and A. Kacimov, "Seawater intrusion in the coastal aquifer of Wadi Ham, UAE," IAHS PUBLICATION, vol. 312, pp. 315-325, July, 2007.

[12] Food and Agriculture Organization (FAO), "Irrigation in the Middle East Region in figures," AQUASTAT Survey, 2008, pp. 23-122, 185214, 339-374, Rome, Italy, 2009.

[13] M. Sherif, M. Mohamed, A. Kacimov, and A. Shetty, "Assessment of groundwater quality in the northeastern coastal area of UAE as precursor for desalination," Desalination, vol. 273, pp. 436-446, June, 2011.

[14] W. Abrams, E. Ghoneim, R. Shew, T. LaMaskin, K. Al-Bloushi, S. Hussein, M. AbuBakr, E. Al-Mulla, M. Al-Awar, and F. El-Baz, "Delineation of groundwater potential (GWP) in the northern United Arab Emirates and Oman using geospatial technologies in conjunction with Simple Additive Weight (SAW), Analytical Hierarchy Process (AHP), and Probabilistic Frequency Ratio (PFR) techniques," Journal of Arid Environments, vol. 157, pp. 77-96, Oct, 2018.

[15] R. H. Al-Dabbagh, "Water resources management in Sharjah, UAE," ISESCO Journal of Science and Technology, vol. 12, pp. 38-53, 2016.

[16] K. Wahlin and A. Grimvall, "Roadmap for assessing regional trends in groundwater quality," Environmental Monitoring and Assessment, vol. 165, pp. 217-231, June, 2010.

[17] A. G. Yilmaz, M. A. Imteaz, S. Gato-Trinidad, and I. Hossain, "Climate change finger prints in mountainous upper Euphrates Basin," Int Journal Civil Environmental Engineering, vol. 3, pp. 13-21, Jan, 2011. 
[18] A. G. Yilmaz and B. J. C. Perera, "Extreme rainfall nonstationarity investigation and intensity-frequency-duration relationship," Journal of Hydrologic Engineering, vol. 19, pp. 1160-1172. July, 2013.

[19] A. G. Yilmaz, I. Hossain, and B. J. C. Perera, "Effect of climate change and variability on extreme rainfall intensity-frequency-duration relationships: A case study of Melbourne," Hydrology and Earth System Sciences, vol. 18, pp. 4065-4076, Oct, 2014.

[20] A. G. Yilmaz, "The effects of climate change on historical and future extreme rainfall in Antalya, Turkey," Hydrological Sciences Journal, vol. 60, pp. 2148-2162, Dec. 2015.

[21] A. G. Yilmaz and B. J. C. Perera, "Spatiotemporal trend analysis of extreme rainfall events in Victoria, Australia," Water Resources Management, vol. 29, pp. 4465-4480, Sep, 2015.

[22] A. A. Masoud, K. Koike, H. A. Mashaly, and F. Gergis, "Spatio-temporal trends and change factors of groundwater quality in an arid area with peat rich aquifers: Emergence of water environmenta problems in Tanta District, Egypt," Journal of Arid Environments, vol. 124, pp. 360-376, Jan. 2016.

[23] T. S. Narany, A. Z. Aris, A. Sefie, and S. Keesstra, "Detecting and predicting the impact of land use changes on groundwater quality, a case study in Northern Kelantan, Malaysia," Science of the Total Environment, vol. 599, pp. 844-853, Dec, 2017.

[24] A.G. Yilmaz, A. Shanableh, T. Merabtene, S. Atabay, and N. Kayemah, "Rainfall trends and intensity-frequency-duration relationships in Sharjah city, UAE," Int. J. Hydrology Science and Technology.

[25] N. E. Heckman and J. O. Ramsay, "Penalized regression with modelbased penalties," Canadian Journal of Statistics, vol. 28, pp. 241-258, June, 200.

[26] A. A. Masoud, K. Koike, H. A. Mashaly, and F. Gergis, "Spatio-temporal trends and change factors of groundwater quality in an arid area with peat rich aquifers: Emergence of water environmental problems in Tanta district, Egypt," Journal of Arid Environments, vol. 124, pp. 360-376, Jan, 2016

[27] L. Evers, D. A. Molinari, A. W. Bowman, W. R. Jones, and M. J. Spence, "Efficient and automatic methods for flexible regression on spatiotemporal data, with applications to groundwater monitoring," Environmetrics, vol. 26, pp. 431-441, Sep, 2015.

[28] A. G. Yilmaz, A. Shanableh, R. Ruzouq, N. Kayemah, and A. Idris "Spatio-temporal trend analysis of groundwater quality data in Sharjah, UAE," Hydrology and Earth System Sciences.

Copyright $\odot 2020$ by the authors. This is an open access article distributed under the Creative Commons Attribution License which permits unrestricted use, distribution, and reproduction in any medium, provided the original work is properly cited (CC BY 4.0).

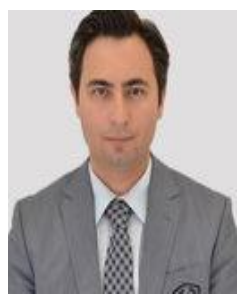

Abdullah Gokhan Yilmaz has a $\mathrm{PhD}$ in civil (water) engineering from the Swinburne University of Technology, Australia. He is currently working at the University of Sharjah in Civil and Environmental Engineering Department. His research interests are climate change hydrology, rainfall-runoff modelling, GIS and remote sensing applications in water resources management and extreme rainfall, flood and drought analysis. He has delivered variety of courses at undergraduate and graduate levels including water resources engineering, fluid mechanics, hydraulic engineering and design, engineering economics, irrigation water management and gis in water resources engineering.

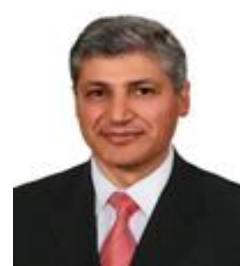

Abdallah Shanableh is a Professor of Environmental Engineering in the Department of Civil and Environmental Engineering and Director of the Research Institute of Sciences and Engineering at the University of Sharjah, United. He received his BSc (1986) in Civil Engineering from the University of Jordan, Jordan, and his MSc (1988) and PhD (1990) from the University of Texas at Austin, USA He served in a number of professional, academic and administration positions in the USA, Jordan, Australia, Japan and the UAE. He won a number of teaching, research and community and professional service awards. He is the founder and general chair of the international forum on Engineering Education (IFEE) and Towards Sustainable development International Conference (TSDIC). His research interests include water and wastewater treatment, waste management, recovery of energy and material resources from wastes, and engineering education.

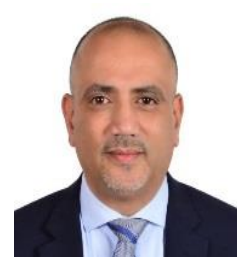

Rami Al-Ruzouq is an associate professor of geomatics engineering in the Department of Civil and Environmental Engineering and Coordinator of the Sustainable Civil Infrastructure Systems (SCIS) Research Group at the University of Sharjah. He served in a number of professional, academic and administration positions in the USA, Canada, Jordan, and the UAE. He is a member of many local and internationally scientific societies (American Society of Photogrammetry and remote sensing (ASPRS), Mapping Sciences Institute, Australia, Jordan Engineers Association and the Institution of Geospatial and Remote Sensing Malaysia). His research interests include: Geographic information system (GIS) and remote sensing for Hazard mapping and environmental modeling, spatio-temporal analysis for urban growth and transportation planning, photogrammetry and 3D-Modelling for construction and archeological documentation, underground water mapping and assessment.

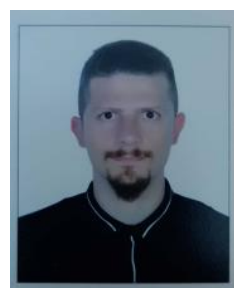

Naseraldin Kayemah is a master of research student in Civil and Environmental Engineering Department at University of Sharjah. His research interests are statistical assessment of hydro-meteorological variables and groundwater hydrology. He is currently working as a Research Assistant and working on spatio-temporal assessment of groundwater resources in United Arab Emirates. 